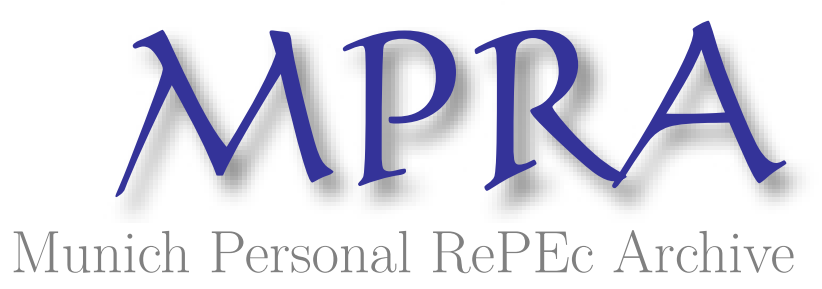

State-Owned Enterprise Reform and Smooth Institutional Transition in China - A Three-Stage Economic Reform Method

Tian, Guoqiang

1996

Online at https://mpra.ub.uni-muenchen.de/41213/

MPRA Paper No. 41213, posted 15 Sep 2012 20:46 UTC 
Chapter 14

\section{STATE-OWNED ENTERPRISE REFORM AND SMOOTH INSTITUTIONAL TRANSITION IN CHINA - A THREE-STAGE ECONOMIC REFORM METHOD*}

\author{
GUOQIANG TIAN \\ Department of Economics \\ Texas A $8 M$ University \\ College Station, Texas 77843 \\ E-mail: gqt7885@venus.tamu.edu
}

This paper addresses the methods of state-owned enterprises' ownership reform and the smooth institutional transition of the economic system in China. By using the theory of endogenous ownership arrangements developed in Tian (1995), a three stage method of China's economic reform will be given. We show that a smooth institutional transition to a market economy needs to go through three stages: (1) economic liberalization; (2) marketization; and (3) privatization. In the first stage, the entry and competition of enterprises of all kinds of ownership make the non-state owned sector of the economy develop quickly. In the second stage, competition among enterprises of all kinds of ownership and the introduction and development of the market system lead to reduction of state-owned enterprises. In the third stage, state-owned enterprises will face large scale bankruptcy and privatization. The first stage began with rural economic reform in China in 1979. The second stage began in 1992. The third stage has not begun and should not be expected too soon. It is preferable to wait about 5-10 years until the non-state owned economy has become a large proportion of the economy, say above $80 \%$ of GNP, and the social security network is almost completed.

\section{Introduction}

Now is a critical time for China's market-oriented economic reform. The economic reform that began in 1979 has achieved great success, resulting in

"I wish to thank Jim Kelley, Liqun Liu and Anne Mckibbin for research assistance, comments and suggestions. Financial support from Private Enterprise Research Center and Texas A\&M University's Program to Enhance Scholarly and Creative Activities are gratefully acknowledged. very impressive changes in China's economic situation. Economic reform in the past 15 years has brought a high rate of economic growth and a dramatic rise in the standard of living in China. From 1979 to 1994, the annual rate of increase in GNP has been 9.5\%. This figure is larger than that of any other country during the same period, and may be without precedent in Chinese history. Currently, China looks like a worksite. Construction of infrastructure and buildings is taking place all over the country. Markets are prosperous and commodities are abundant everywhere.

Great progress has also been made in reforming the economic system. To some degree, there comes the allowance of economic freedom, acknowledgement of personal interest and benefit, adoption of decentralized decision making, and introduction of all kinds of incentive mechanisms. All types of ownership except state ownership, non-state owned enterprises (including collective enterprises, private enterprises, township-village enterprises (TVEs), foreign capital funded enterprises, and joint ventures) have prospered which, in turn, have made the economic system change drastically. State-owned economies share of the total GNP has been dropping quickly. The economy has changed from a mainly publicly owned central command system to a mixed-ownership system with the non-publicly owned sector produced around $60 \%$ of total GNP. From the data released by the state-owned statistics bureau, China Information, the state-owned proportion of industrial gross product was $78.5 \%$ in 1979 , which decreased to $52.4 \%$ in 1991 . That indicates a 2 percentage point annual drop. This trend has accelerated since 1992 with a drop of 4.8 percentage points in 1992 and 4.1 percentage points in 1993. The proportion of GNP produced by state-owned enterprises has decreased to $44 \%$ by 1993 , and the non-state owned sector has become the main engine of the Chinese economy. In 1992 the investment in the non-state owned sector was only $25 \%$ of total investment, but this sector accounted for $69 \%$ of GNP growth. In addition, China has made remarkable progress in introducing market systems. The prices of most commodities are determined by market forces. So far, the reform has helped lay the basis for total marketization and privatization of publicly owned enterprises, which will speed up the process of institutional transition. The 14th National Congress of the Chinese Communist Party held in 1992 decided that China will adopt a market economy, which cleared the ideological road block for a market economy. All of these facts indicate that the transition of China's economy to a market system has so far, been successful both in the sense of results and the experience obtained. 
However, with the deeper development of reform and the acceleration of the transition process, the difficulty of reform increases. There are many fundamental problems that must be solved so that they do not block or slow down the transition process. Some of these problems existed before the onset of reform, but others arose during the transition process. These problems include, among others, (1) the primitive nature of the current market system; (2) the inability of prices to fully reflect the economic relations involved; (3) the imperfection of macro regulating and controlling mechanisms; (4) the non-establishment of a modern enterprise system; (5) severe crises facing state-owned enterprises which are bringing more and more burden to the country's economy; (6) severe government fiscal deficits; (7) many leaders who are slow and in some cases, reluctant to learn how to operate in a market economy and instead tend to resort to old planning methods to solve economic problems; (8) possible social instability caused by the pain by unemployment and inflation; (9) the imperfection and nonexistence of laws and regulations governing labor markets, financial markets, property rights system and social security and welfare systems; and (10) unfair competition resulting from imperfect markets and legal systems during the transition of the economy. Also, some people take public properties into their own private control through their relation networks or embezzlement.

Among the above problems, the most noticeable are the losses incurred by state-owned enterprises. China's state-owned enterprises currently have a capital stock of 2 trillion RMB, excluding the value of the land and real estate they occupy, but their losses are extremely serious. In 1992, one third of the state-owned enterprises were suffering losses. Besides this, approximately another one-third of the state-owned enterprises were just breaking even. However, according to the data released from the recent National Changing Losses for Profits Working Meeting, among the "in budget" stateowned enterprises alone, there were over 16,000 enterprises suffering losses in the first half of $1994,15.5 \%$ more than last year, with the total proportion suffering losses reaching $46.3 \%$. The total loss amounted to 21.97 billion RMB, $26.8 \%$ more than last year and 7 times more than 1985's 2.678 billion. Of the industrial growth, state-owned enterprises have a share of only $6.6 \%$, while non-state-owned enterprises have the remaining share, or $93.4 \%$. Due to the large scale losses of several consecutive years, the state-owned enterprises can hardly contribute to the government's revenue. Moreover, they have become a severe fiscal burden to the country, like a bottomless hole, that goes beyond the country's fiscal ability. For example, the proportion of state-owned enterprises suffering losses was almost $50 \%$ in the first season of 1994, which is double that of non-state owned enterprises and requires a subsidy totaling 15.7 billion RMB from the government. The employees of many poorly run, inefficient state-owned enterprises are living under the poverty line with a very low "basic wage," and sometimes only $60 \%$ of that wage. Life is extremely hard for them. After the wage system reform for officials and employees of the non-production public sector, the employees of many poorly run state-owned enterprises have the lowest wages among all types of occupations, which averages about $200 \mathrm{RMB}$ a month, just half that of the non-public enterprise sector. The solution to the problems of state-owned enterprises has been an important topic, drawing much public attention. Many policy makers and economists suggested large-scale bankruptcy or privatization of the state-owned enterprises which are suffering losses. However, we must first ask if such bankruptcy is the key to China's economic reform and if the conditions required for large scale bankruptcy have already been satisfied. Also, we need to better understand the role of many unemployed workers in the social stability and the main blockades to enforcing bankruptcy.

Since there are many problems to be solved during the transition period, the relevant question is which are most urgent and in what order they should be solved. When trying to make decisions on priorities, we must take into account many factors such as, the costs and risks of reform, feasibility, stability, timing, and physical and mental capability to undergo changes. We need to consider economic conditions and the political environment, historical traditions, cultural background and social structure, and also need to consider if the methods of reform can result in a high speed of economic growth, as well as a rise in people's living standards. Only when taking into account the previously mentioned factors, can one propose a proper method of reform. I think that the method of transition is the most fundamental strategic issue to be considered. Closely related is the method of ownership reform of state-owned enterprises. These important problems determine the success and difficulty of reform. In this paper we try to give solutions to these problems. Although other problems may also be important, they are limited to specific stages of reform and are only tactical problems. For discussions of these problems, see Hussain (1994), Jefferson, Rawski, and Zheng (1992), Jefferson and Rawski (1994, Perkins (1994), Summerfield (1994), and Tian (1994b, 1994c, 1994d) among many others.

In this paper, I will discuss the strategic problem of the Chinese economic institutional transition process and their methods of state-owned enterprise ownership reform and of smooth institutional transition in China by 
using the theory of endogenous ownership arrangements developed in Tian (1995). Under the requirements of optimal ownership arrangements and the social stability in the transition period, a three-stage method for China's economic reform will be given. I will show that three stages are needed to guarantee the economy's smooth transition to a market economy. These three stages are: (1) economic liberalization; (2) marketization; and (3) privatization. In the first stage, the creation and competition of enterprises of all kinds of ownership make the non-state owned sector of the economy develop rapidly. The growth guarantees the lasting development of the economy, which, in turn, provides the material base for the reform in later stages. At the same time, the growth raises the people's sense of participation and wins their support. In the second stage, continual competition among enterprises of all types of ownership and the introduction and development of the market system induce reduction of state-owned enterprises (workers, capital and technology drain from state-owned enterprises). In the third stage, state-owned enterprises will face large scale bankruptcy and privatization.

The first stage began with the rural economic reform in 1979. The second stage began on or about 1992, marked by the resolution on marketization by the 14th National Congress of the Chinese Communist Party. The third stage has not yet begun and I do not think the time is yet right to begin. It may be preferable to wait until a non-state owned economy represents a large proportion, say above $80 \%$ of GNP and the social security network has more or less been set up to carry out the third stage operations. I estimate that it needs 5-10 years for the third stage to begin. This is based on a 2-4 percentage point annual drop of the proportion of state-owned economy in the total economy. I will discuss the three stages in detail and explain that, under the current Chinese situation, the three stage gradual transition method may be the best one in the sense that it can make the economy grow rapidly and simultaneously guarantee relative social stability. To understand the rationality and feasibility of the three-stage transition, let us first introduce the theory of endogenous ownership arrangements for imperfect markets and transitional economies which is developed by Tian (1995), and discuss the prerequisite conditions for an economy to operate efficiently in the following two sections.

\section{The Optimal Ownership Arrangements}

Institutional transition is one of the hot research fields in the current economics literature. However, in the author's opinion it seems that there is no satisfactory theoretical framework extant in this field. Most of the studies in this field (and the related policy recommendations) are based on conventional neoclassical economic theory, traditional property rights theory (contractual theory), or insights provided by the theory of the firm, information economics, and mechanism design theory. Some of the basic assumptions underlying these theories are not satisfied by transitional economies. The main focus of study of these standard theories is modern industrialized economic institutions where mature market systems are well established, and where there exists a high degree of economic freedom and decentralization. A conventional wisdom from these theories is that clearly defined private property rights are the prerequisite condition for economic prosperity. It is because of this conventional wisdom that many economists believe that rapid privatization is a necessary first step for institutional transition from a centralized command economy to a decentralized free market economy.

However, China's experience over the past 17 years of a high rate of economic growth without a large scale privatization and the recent experience in Eastern Europe and the former Soviet Union of sharply decreasing GNP after implementing rapid privatization challenge this conventional wisdom and the belief in rapid privatization as the first step of institutional transition. The experience of partial and gradual reform coupled with rapid economic growth puzzled many economists, and they asked why China has grown so fast when the conditions thought to be necessary for growth were absent (Blanchard and Fischer, p. 4, 1993). On the other hand, the rapid privatization in Eastern Europe and the former Soviet Union has not been without serious problems. These countries have experienced continued economic turmoil and significant declines in output. Thus, the vigorous Chinese non-state sector operating under the constraint of poorly defined property rights and the lethargic economic performance in Eastern Europe and Russia after rapid, albeit problematic, privatization seems to contradict these theories. These counter examples arouse some suspicions about the conventiona wisdom and the generality and applicable range of the standard theories.

Indeed, the conclusion that private ownership is the optimal property rights arrangement is based on a set of presumptions which are not satisfied by transitional economies and other irregular economies. All these theories assume that ownership arrangements are exogenously given, and that the economic environments under consideration are "regular" in the sense that they provide a high degree of economic freedom and decentralization, as well as the existence of a highly mature and perfect market system. ${ }^{1}$ However,

${ }^{1}$ For convenience, an economic environment will be called an irregular economic environment if it is not regular. 
economic reality seldom adheres very closely to these assumptions. Even while these assumptions may be approximately correct for modern industrialized economic institutions, they are extremely unsuitable to the institutions of command economies, transitional economies, economies characterized primarily by state ownership, and economies with a great degree of government intervention that hinder many socially worthwhile transactions and restrict economic freedom. Thus, there is a need to develop a new theoretical framework which can be used to explain existing phenomena in the real world and study the choice problem of institutional arrangements when economic environments are irregular.

Tian (1995) developed a more appropriate theoretical framework which improves and generalizes the conventional property rights theory to include irregular economic environments where economic freedom and decentralization may be bounded and markets may be absent, immature or imperfect. This new property rights theory is more descriptive and more closer to economic reality. It rationalizes ownership and property rights arrangements, and relates a firm's optimal ownership arrangement to the degree of economic freedom and decentralization, and market perfection. The optimal ownership arrangement is endogenously chosen and is based on an efficiency comparison of state ownership, collective ownership, and private ownership.

The new property rights theory catches the crucial features of imperfect markets and bounded economic freedom and decentralization. In the model, besides using two usual physical factor inputs: capital and labor, production uses two other resources: management ability and governmentrelations ability. These two resources are of crucial importance for effective production under a high degree of government intervention or when a market is absent or far from perfect. In general, private entrepreneurs have superior abilities in management and bureaucratic managers have superior abilities in government relations and procurement of government owed or controlled resources. The status (degree) of market perfection, decentralization, and government intervention is summarized by a number $\rho$, between zero and one, which is introduced to capture the relative importance of these two abilities. The closer $\rho$ to zero, the more centralized, constrained, or imperfect is the economic environment. Assume there are three types of ownership arrangements for production: private ownership which can take advantage of management ability; state ownership which can take the advantage of government-relations ability; and collective (mixed) ownership which affords an opportunity for specialization and the possibility to take advantage of management and government-relations abilities.
A basic question the paper will answer is which ownership arrangement is relatively more efficient compared to the others in terms of the net income of an individual. Tian (1995) showed that private ownership would dominate state and collective ownership arrangements if the degree of economic freedom and decentralization is very high and the market is close to perfect; that state ownership would dominate private and collective ownership arrangements if a high degree of economic irregularity exists; and that collective ownership would dominate state and private ownership arrangements if the degree of irregularity of the economic environment is somewhere around the middle.

\section{Prerequisite Conditions for Prosperity}

I should point out that the above results on optimal ownership arrangements should not be interpreted to argue the advantage of state and collective ownership arrangements. Rather, they should be used to argue the importance of economic freedom and decentralization, and consequently the importance of improving economic environments. Although a state ownership or collective ownership arrangement may dominate a private ownership arrangement when the economic environment is irregular, this does not mean that a state ownership or collective ownership arrangement within an irregular economic environment will dominate a private ownership arrangement within a regular economic environment. In fact, transactions in irregular economic environments carry high costs and some extra resources such as government relations have to be used in such irregular economic environments. The desire to transform an economic system is not fully based on the two basic welfare economics theorems-the theoretical foundation for economists' positive view of the market mechanism. ${ }^{2}$ Rather, it is primarily due to the unacceptable low

${ }^{2}$ These two theorems deal with the relationship between competitive equilibria and (Pareto) efficiency of resource allocation. The so-called First Theorem of Welfare Economics states that every perfectly competitive equilibrium allocation is Pareto efficient in the sense that there is no alternative feasible resource allocation leaving everyone at least as well off and making some members in the society better off. It pre-supposes the absence of externalities and a certain nonsatiation property of individual preferences which implies that the desires of individuals are never satisfied. The Second Theorem of Welfare Economics states that any Pareto efficient allocation can be achieved as a perfectly competitive equilibrium allocation by an appropriate redistribution of assets. It also postulates the absence of externalities and nonsatiation property, and makes several additional significant assumptions, including continuity and convexity of individuals' preferences. 
efficiency of the planned economy in practice. ${ }^{3}$ Thus, private ownership will be more efficient. To reach the efficient allocations of resources, one nevertheless should adopt private ownership as the final goal. However, the procedure for reaching such a goal should not privatize state-owned firms rapidly, but should be to first improve economic environments, i.e., improve the four prerequisite conditions for an economy to work well-acknowledgement of people's self-interest, freedom of economic choice, decentralization in decision making, and usage of incentive mechanisms. The fact that the market system can solve many problems which cannot be solved in a planned economy is simply due to the satisfaction of the four prerequisites by a market system. We can even say that the four prerequisite conditions are the "four basic principles" for any economic system to work well.

The first prerequisite is acknowledgement of people's self-interestedness. In economics, while showing the optimality of the competitive market mechanism, ${ }^{4}$ one of the most basic assumptions made is that people are self-interest (or rational) and will maximize their welfare under various constraints such as budget constraints, price constraints, production technology, and law-policy, etc. Human beings' self-interest is an inevitable reality. Acknowledging such self-interest is a responsible attitude toward solving problems of society. On the contrary, denying human self-interest and treating social economic problems on the basis of altruism, as before reform, has resulted in tragedy. Self-interest is the engine of economic development and social progress. The great success of the "production responsibility system" in the countryside of China lies in the acknowledgement of the peasant's

${ }^{3}$ In most of this paper the term efficiency is used in the sense of Pareto efficiency. But in the present context it is convenient to introduce two other usages of this term. First is efficiency within a firm. A firm is internally production efficient if no output can be increased given a level of inputs. Second is efficiency in the aggregate of all firms in an economy. An economy is production efficient in the aggregate if no aggregate output can be increased given a level of aggregate inputs. Note that, under the assumptions of monotonic preferences, Pareto efficiency implies internal production efficiency and aggregate efficiency, but the converse may not be true because production-efficiency does not take into account consumers' preferences. Hence, the "wrong" goods might be produced in production-efficiency manner, thus misallocating resources. Also, aggregate production efficiency implies internal production efficiency but not vice versa. Each firm might be internally production efficient without maximizing the aggregate outputs for the given aggregate input levels. This would happen if firms with low productivity were producing goods that other firms with high productivity can produce.

$$
{ }^{4} \text { See Varian (1992). }
$$

self-interest or individual interest and benefit. Before using the production responsibility system, peasants lacked incentive to work hard because they were worried that their own products would be shared by others and meanwhile they themselves had incentive to share other's products. After using the production responsibility system, the peasants knew they were working for themselves therefore, their production enthusiasm increased significantly.

The second prerequisite condition for an economic system to perform well is the freedom of economic choice, that is, allowing people freedom to choose among economic alternatives so long as they do no harm to others. Freedom of choice based on mutual benefits and cooperation through voluntary exchange plays a fundamental role in an economic system characterized by decentralized decision making and is also a basic requirement necessary to achieve optimal resource allocation in a competitive market mechanism. In the past 15 years, Chinese reformers have done many things. Most important, they have loosened restrictive policies, i.e., producers and consumers have been given more freedom of choice. For example, although the central government has given little financial aid to the coastal areas, these areas have been developing very fast due to relaxed economic policies.

The third prerequisite condition for an economic system to perform well is decentralized decision making. Production or consumption decisions should be made by individual producers or consumers instead of by high ranking departments. Decentralized decision making is preferred because the economic information involved cannot be completely obtained by a bureaucracy. Decentralized decision making can save much of the cost of information processing and information transmission and thus, use economic information more efficiently. A command economic system mainly uses centralized decision making while a market system primarily uses decentralized decision making.

The fourth prerequisite condition for an economic system to perform well is the introduction of various incentive compatible mechanisms. Since agents have private information and may find it advantageous to distort the information they reveal, they may use such information to advance their own interests. This implies that the basic principle of designing a mechanism, rule, or regulation with incomplete information would provide individuals with appropriate incentives so that individuals' interests are consistent with the goals of the organization. Better results are often obtained by using incentive mechanisms, such that individuals are motivated to act in the desired manner by the rewards they receive from doing so, rather than as a 
results of orders. One important problem facing an economic system is how to stimulate people's energy or incentives to work hard through institutional arrangements. If an economic system fails to stimulate incentives, but rather succeeds in producing sluggards and idlers, then it is bound to fail at some point in the future. The market mechanism successfully solves the incentive problem. The market system sends correct incentives to self-interested people to induce them to work for the society. This is called incentive compatibility. ${ }^{5}$ Whether or not incentive compatibility can be achieved is of concern to the fate of an economic system.

In addition, to incentive compatibility, the most salient feature of the market system is its efficiency in using information. ${ }^{6}$ In the market system, economic information can be transmitted efficiently through prices. We should point out, however, that before a market system is fully established, people should not expect the imperfect market system to solve informational problems perfectly. We must bear in mind that many problems such as unemployment, inflation and deficits on the macroside of the economy and inefficiency of firms on the microside of the economy are inevitable in transitional periods. Nevertheless, we should begin the transition in a good condition. Since developing new markets and establishing a mature market system are very time-consuming and costly (although untying government intervention, allowing economic freedom, and introducing incentive mechanisms may be relatively easy and less time-consuming), complete privatization is not the optimal choice for a irregular economic environments according to the new property rights theory. In the transitional period, collective ownership is a more efficient response given current state of the transition. Only when the economic environment is sufficiently close to perfect, one can privatize state-owned firms.

\section{The First Stage: Economic Liberalization}

The first stage of the transition process is characterized by economic liberalization. Much of the past 17 years was spent in this stage. The first step of reform is establishing and improving the basic prerequisite conditions for

${ }^{5}$ This terminology is widely used in the mechanism design literature. Incentive compatibility is a basic requirement for an incentive mechanism. For the discussion of this concept and the design of incentive mechanisms under various ownerships, see Hurwicz (1972), Groves and Ledyard (1979), and Tian (1989, 1990, 1991, 1994a).

${ }^{6}$ See Hurwicz (1986) and Jordan (1982). an economic mechanism to perform well. The reform during this stage has greatly changed the Chinese people's values, thinking and behavior. People have used their specialties and personal networks to the best of their ability to make money. (Although some people make money through irrational and illegal ways). During this period, people have gradually come to realize that a self-interest is an inevitable part of human behavior. After this reform, the people have gained freedom of economic choice to a great degree. In rural areas, peasants have had the rights to use the land even though they have not been given ownership, hence they can determine what products to produce. In the cities, people can choose to stay in a state-owned enterprise or can undertake the risk of working for a non-state owned enterprise. At the same time, decentralized decision making and various types of incentive mechanisms have been adopted. Decision power has been granted to agents who are directly responsible for results. With incentive mechanisms, the individuals' goals (indirectly) serves the benefit of society as a whole. Agents work hard and effectively, because they work for themselves. These factors are the main reasons for the quick growth in the economy.

China's economic reform began in rural areas. Starting with the improvement of the above four basic conditions. The reform has been characterized by acknowledging peasants' self-interest, shifting production decision power to peasants and enhancing peasants' incentives to work. With such reform, peasants' production enthusiasm has increased and the Chinese agricultural situation has changed dramatically. Of course, there are some problems with the reform of the production responsibility system. The most serious problem is that peasants are reluctant to make long-run investments on land due to the short terms of contracts. This has resulted in predatory production, characterized by the decreasing fertility of the land. Thus, contracts with longer terms are needed. If the terms are long enough, the peasants, provided with the rights to use and transfer the land, will treat their rented land as if they owned it. This is true because the ownership and usage rights of land can be separated.

Since the reform has achieved great success in rural areas, it was introduced to other industries and geographic areas. For example, individual enterprises and private enterprises were allowed. Furthermore, foreign capital funded enterprises and joint ventures are not only allowed to "exploit" Chinese people, but can also enjoy some favorable treatment. In these enterprises, people's self-interest is better acknowledged; they have more freedom of choice and decision making is more decentralized than in state-owned enterprises. The result has been the prosperous development of non-state owned 
enterprises. The non-state sector has become the main engine of the Chinese economy. This is true not only for the rapid development of coastal areas, but for the whole country. In 1992, investments in the non-state owned sector was $25 \%$ of total investment, but the non-state owned sector accounted for $69 \%$ of GNP growth. This is an indirect, spontaneous and intangible transition process in which the non-state sector developed from small-scale to large-scale. At the same time, the state-owned sector did not necessarily shrink. Potential conflicts between reform and the state-owned sector has been successfully avoided at this early stage. With the development of the non-state sector, the market system has developed, pushing the state-sector to improve its economic efficiency. The economy has changed from a mainly publicly-owned central command system to a mixed system with the nonpublicly owned sector having a share of over $50 \%$ of GNP. The share of total GNP produced by state-owned firms has dropped from $80 \%$ in 1978 to $44 \%$ in 1993. How did this happen? Does this mean that $30 \%$ of state-owned enterprises were bankrupt or sold in the past 15 years? The answer is no. Actually, there were fewer bankruptcies of state-owned enterprises during this period. The correct answer lies in the fact that non-state owned enterprises have developed very rapidly, causing the change in the state-sector/non-state sector ratio. Among those non-state enterprises, the township-village enterprises has played a very special role. The dramatic development of this group of enterprises has made it possible for the state's share of total GNP to drop 4 percentage points each year for the past 2 years. This trend can only become stronger. Today about 70population lives in rural areas. It is estimated that, after China has become a modern industrial society, only about $20 \%$ of its population will be needed for agricultural production. As long as current policy of reform is not reversed and the non-state economy is allowed to develop, the non-state share and non-agricultural share of total GNP will probably be very high. The situation of the coastal areas of Guangdong Province best represent this trend. The percentage of people living in rural areas has dropped to $20 \%$ today from $80 \%$ before reform. This is more significant if we bear in mind that these areas have absorbed more than 6 million people in the labor force from other areas.

\section{The Second Stage: Marketization}

The second stage of the transition process is characterized by marketization. China is now at this stage. Its beginning was marked by the 14th National Congress of the Chinese Communist Party's resolution on marketization. On one hand, the market oriented reform has achieved great success. As mentioned previously, some of the prerequisite conditions for an economic system to perform well have almost been satisfied or have greatly improved. Those conditions include the acknowledgement of people's self-interest, allowance of freedom of economic choice, adoption of decentralized decision making, and the introduction of various incentive mechanisms. After these reforms were implemented, market share of non-state owned enterprises in the total economy increased significantly, as have people's ability to undergo market risk. People's demands for a complete marketization are growing. On the other hand, during the current stage of reform, as mentioned in the introduction, there are still many problems to be addressed. Most of these problems are due to the imperfection of the current market system. Therefore, the completion of the marketization reform and the perfection of the market system must be under way. A perfect modern market system not only requires flexible and open markets for all kinds of products and economic freedom, but also requires the cooperation of other systems, including the price system, the macro economic regulation system, the modern enterprise system, tax (income distribution) system, social security system, law system, antitrust system, and labor and financial systems. A great deal of work remains to cultivate and perfect these systems. The only way to achieve this is by the incessant introduction of the market system. With the marketization process, the economy is characterized by the reduction of state-owned enterprises. This is due to their relatively low efficiency and losses suffered by the state-owned enterprises.

Due to the marketization reform, the state-owned enterprises have to compete with other types of enterprises with different types of ownership. Although, the efficiency of the state-owned enterprises has increased during economic reform, it is in general, still lower than that of non-state owned enterprises due to the vagueness of property rights, historical burdens, and the inflexibility of its market mechanism.

What methods should we adopt to solve the problem of state-owned enterprises? Large-scale bankruptcy and privatization are the most often used methods in modern transition economies. Is such bankruptcy or privatization the key to China's economic reform? Have the conditions required of large-scale bankruptcy or privatization already been satisfied? My answer is no. We must wait for more time before resorting to these policies. In a competitive market, a firm can go bankrupt and leave all of its workers unemployed due to poor management, old technology, inferior quality or bad luck. However, in a mature modern market system this would not induce social instability because of social security and unemployment relief systems. 
However, in China, since there are no social security and unemployment relief systems for large-scale bankruptcy. Since the number of workers in the stateowned enterprises is large, there is no way for the government to finance the potential burden of unemployment without a developed labor market. But, we know that the current labor market is far from developed. Even without bankruptcy of state-owned enterprises, there are 12 million people to be employed each year, including five million that are laid off from stateowned enterprises. Society cannot be stable with massive unemployment. If a large proportion of people dropped in the economic-social ranks and faced hard times, they would certainly lose their psychological balance and accumulate anti-reform moods. Thus, China should be very careful when adopting large-scale of bankruptcy. It would be better to postpone largescale bankruptcy until the labor market and social security system are set up. State-owned enterprises can play a vital role of social security during this period, since those who cannot find their way into non-state owned enterprises can stay in state-owned enterprises. Although, high subsidies are needed from the government to support the state-owned enterprises which incur losses, this subsidy should be much less than that required to adequately support unemployed workers as long as the revenue of a state-owned enterprise can cover the wage part of the cost of production. At the same time, workers of state-owned enterprises should be guaranteed more freedom of choice and be encouraged to leave for non-state owned enterprises or to open their own small business.

Letting the number and size of state-owned enterprises decrease naturally without large-scale bankruptcy or privatization in this stage is not only necessary for social stability, but is also feasible. Since workers in stateowned enterprises have the right to choose whether or not to stay and workers in poorly run state-owned enterprises have the lowest wages in all types of occupations, more and more of them are willing to take the risk and work for non-state owned enterprise. This greatly speeds up the reduction in the number and size of the state-owned enterprises. On my trips to China in the past years, I found that a fairly large proportion of taxi drivers, individual businessmen (and women), and workers in non-state owned companies and privately owned firms were from state-owned enterprises. In addition, the capital drain from state-owned enterprises is severe, with a loss of a $\$ 100$ million a day.

How long should we wait before using large-scale bankruptcy or privatization? I think we must wait for at least 5-10 years. First, the privatization is not the optimal choice at the current status of the transition period. The market system has not been mature, and economic freedom is still bounded in a great degree. According the new property rights theory, the private ownership arrangement is not the best choice. Second, state-owned enterprises still produce around 40China adopted a privatization process similar to those used in Europe, the production of the state-owned enterprises would certainly drop in the first few years, which in turn would result in a drop in total production. In that case, the people's living standards would also drop. Third, with the sharp reduction of state-owned enterprises, many workers would be unemployed, which would influence social stability if the labor market and social security system have not been set up. Fourth, due to China's social structure and cultural tradition, the Chinese people's psychological capability to undergo changes is not as great as that of Eastern European people. These are the main reasons, I argue, that we must wait until the production of non-state owned enterprises has reduced a large proportion, say $80 \%$ or above of GNP, the country has enough comprehensive social-economic power, and the social security system has been set up, to adopt large-scale bankruptcy or complete privatization policies.

During the marketization process of the second stage, while the Chinese government allows state-owned enterprises to suffer losses with superfluous workers, the government should improve economic environments. Specifically, it should do the following: (1) allow labor motion to form the labor market; (2) set up and improve the social security system, which is a necessity for any modern market mechanism; (3) for middle to small sized state-owned enterprises, we can use auction, sell-out, stock cooperative or stock-sharing system to change the public ownership; (4) adopt a stocksharing system in those large to middle sized state-owned enterprises with relatively higher efficiency; (5) for those middle to small sized state-owned enterprises with recurring and severe losses, try bankruptcy in a small scope, and let them go bankrupt in the near future; (6) design appropriate incentive mechanisms to enhance the energy of managers and workers of state-owned enterprises. For instance, long-run contracts or leases should be used for middle to small sized state-owned enterprises, especially for the third industry state-owned enterprises. The results of incentive mechanism design theory tell us that, even for public ownership, efficient allocations may be achieved through some appropriately designed incentive mechanisms. ${ }^{7}$

\footnotetext{
${ }^{7}$ See Hurwicz (1979), and Tian and Li $(1994,1995)$.
} 


\section{The Third Stage: Privatization}

The third stage of the transition process is characterized by privatization. As we mentioned, we are not in this stage yet, and it should not begin on a large-scale until the non-state owned sector accounts for a large proportion of GNP, and the social security system has been set up. We now turn to the question of how China should privatize the state-owned enterprises when the required conditions are satisfied. We now turn to this question.

Influenced by the success of the introduction of the contract system in rural reform, this system was used for state-owned enterprises in earlier years. But the results were not that very satisfactory. We know that property rights include two important aspects: the significance of ownership and the right to use the property ${ }^{8}$. Well-defined property rights can offer the right incentives to the economic agents involved. In the rural reform, the right to use land and land ownership were separated by the production responsibility system with the latter belonging to the public and formerly going to the peasants. With the right to use the land to their discretion, peasants' energies were stimulated and the purpose of the rural reform was realized. In the early years of ownership reform, people used these contracts which separate ownership and the usage rights on enterprises in non-agricultural sectors, thinking that by doing so the workers' energies could also be stimulated without the loss of physical capital ownership by the state. The reasons that the results from the city reform and the rural reform are so different, although the same ideas were used, are complicated. One main reason lies in the differences between land and other production factors. The supply of land is almost inelastic, land cannot depreciate, and the fertility of land decreases very slowly even without care. These characteristics guaranteed the success of separation between the ownership of land and the right to use land. For example, land in Hong Kong belongs to the government and one must rent land from the government. Although, people do not have the ownership, they have the right to use, the right to a return, and the right to transfer (lease contract). Physical capital can depreciate and devaluate very fast, like machinery, their users would have incentive to overuse them during the term of the contract without maintaining or fixing them if they do not have ownership. Since the contractor does not share much of the risk of capital loss, there is a tendency for the initial capital investment to be too large (more than enough from an

${ }^{8}$ For detailed discussions, see Alchian and Demsetz (1972), Demsetz (1972), and Furubotn and Pejovich (1974). efficiency point of view). The failure of these early attempts, people realized the inevitability of ownership transformation for the state-owned enterprises.

There are many ways to make such a transformation, such as to sellout, auction, divide-up, or put on the stockmarket. Sales or auctions induce the complete clarification of property rights. Hence, by the Case Theorem, they can result in efficient resource allocation if the costs of clarifying the property rights are negligible. A problem with these two methods is that the productive capital would be held by only one or very few people which, due to its unequal distribution, could not be easily accepted at this stage of reform. The stock-sharing system sells the property rights to a relatively large population by selling shares, which would result in relatively equal distributions. However, there are still some problems with the existing stock-sharing systems. That is, too high of a proportion of shares with ill-defined property rights belong to the state, and have government control over personnel. Many state-owned enterprises with newly adopted stock systems are operated in much the same way as before. As the result of this, workers have not taken very much interest in such stock systems. Many workers were forced to buy shares of their own enterprises. They were concerned that while the state underwent all losses, it tried to have the workers share in the loss. Their anxiety is rational and reasonable, since the government is the largest shareholder discretion over management and personnel. Managers still lack incentives to work efficiently for the benefit of the enterprises. It is true that a stock system alone cannot solve the efficiency problem, but as I proposed in other papers (cf. Tian (1994b)), there is a simple and effective way to handle this difficulty. That is, the state's shares, no matter how large, should be seen as special shares and the persons legally standing for these shares should not take part in decisions on production activities. This means that the managers and the Board of Directors should be elected by the individual share holders. From my first-hand visits to the township-village enterprises (TVEs) in the Zhejiang Province in 1994, many TVEs seem to use methods very similar to these to set up the stock system, which obtained very good results. This indirectly proves that this method should be suitable to the property rights structure reform for the state-owned enterprises.

\section{Conclusion}

In this paper, we discussed the strategies of state-owned enterprise ownership reform and the smooth transition of the economic system in China. We gave the rationale for a three stage method of economic reform with some degree of "gradualism." I argued that in the early stages of China's reform, the most 
important and appropriate thing which was done was significant improvement in the implementation of the prerequisite conditions for an economic mechanism to perform well,instead of marketization or privatization. This is important because of the social structure, economic condition, cultural background, historical tradition and political stability in China. The reform must begin with the improvement of the required conditions, with no one or no sector suffering in the first place. Its positive effects can be seen immediately. To the contrary, Russia and other Eastern European countries adopted a different approach to the institutional transition. The method of reform used in Russia and other Eastern European countries, which is called "shock-therapy," privatized first, while China has not yet reached that stage. The Russian privatization reform resulted in a sharp drop in GNP in the short-run. For example, during the period from 1991 to October of 1994, the GNP in Russia dropped $50 \%$. The inflation has been $16,000 \%$ since largescale privatization began. China's method so far can be characterized by a gradual transition process in which, as the market system improved, the economy grew incessantly. As long as we follow this method in the future, the economic system transition can be smoothly achieved.

\section{References}

A. A. Alchian and H. Demsetz, "The Production, Information Costs, and Economic Organization," American Economic Review, 62 (1972), 777-795.

Blanchard, O. J., and Fischer, S., NBER Macroeconomics Annual, 1993, Cambridge: MIT Press, 1993,.

R. H. Coase, "The Problem of Social Cost," Journal of Law and Economics, 21 (1960), 1-44.

H. Demsetz, "Towards a Theory of Property Rights," American Economic Review, 57 (1972), 347-359.

E. G. Furubotn and S. Pejovich, "Introduction: The New Property Rights Literature," In Erik G. Furubotn and Svetozar Pejovich, Eds. The Economics of Property Rights, Cambridge MA: Ballinger, 1974.

T. Groves and J. Ledyard, "Incentive Compatibility Since 1972," Chapter 2 in: Information, Incentive, and Economic Mechanisms, ed. by T. Groves, R. Radner, and S. Reiter, (University of Minnesota Press), 1987.

L. Hurwicz, "On Informationally Decentralized Systems," in Decision and Organization (Radner, R. and C. B. McGuire, Eds.), Volume in Honor of J. Marschak, North-Holland, 297-336, 1972.
L. Hurwicz, "On Informational Decentralization and Efficiency in Recourse Allocation Mechanism," in: Studies in Mathematical Economics, ed., by S. Reiter, Mathematical Association of America, 1986.

A. Hussain, "Social Security in Present-Day China and Its Reform," The American Economic Review, 84 (1994), 276-280.

G. H. Jefferson and T. G. Rawski, "Enterprise Reform in Chinese Industry," Journal of Economic Perspectives, 8 (1994), 47-70.

G. H. Jefferson, T. G. Rawski, and Y. Zheng, "Growth, Efficiency, and Convergence in China's State and Collective Industry," Economic Development and Cultural Change, 40 (1992), 239-266.

J. S. Jordan, "The competitive Allocation Process in Informationally Efficient Uniquely," Journal of Economic Theory, 28 (1982), 1-18.

D. Perkins, "Completing China's Move to the Market," Journal of Economic Perspectives, 8 (1994), 23-46.

T. G. Rawski, "Chinese Industrial Reform: Accomplishments, Prospects, and Implications," The American Economic Review, 84 (1994),271-275.

G. Summerfield, "Economic Reform and the Employment of Chinese Women," Journal of Economic Issues 28 (1994), 715-732.

G. Tian, "Implementation of the Lindahl Correspondence by a Single-Valued, Feasible, and Continuous Mechanism," Review of Economic Studies 56 (1989), 613-621.

G. Tian, "Completely Feasible and Continuous Nash-Implementation of the Lindahl Correspondence with a Message Space of Minimal Dimension," Journal of Economic Theory 51 (1990), 443-452.

G. Tian, "Implementation of Lindahl Allocations with Nontotal-Nontransitive Preferences," Journal of Public Economics 46 (1991), 247-259.

G. Tian, "Implementation of Linear Cost Share Equilibrium Allocations," Journal of Economic Theory, 64 (1994), 568-584.

G. Tian, "The Perspectives and Problems of China's Economic Reform," ModernChina Studies, 40 (1994b), 09-23 (in Chinese).

G. Tian, "Russia Privatization Reform and China Economic Reform: Comparison and Evaluation," mimeo, 1994c.

G. Tian, "The Property Rights Structure of Chinese Township-Village Enterprises and Its Reform," mimeo, 1994d.

G. Tian, "A Theory of Endogenous Ownership Arrangements in Imperfect Market and Transitional Economies," mimeo, 1995.

G. Tian and Q. Li, "An Implementable and Informationally Efficient StateOwnership System with General Variable Returns," Journal of Economic Theory, 64 (1994), 286-297. 
G. Tian and Q. Li, "Ratio-Lindahl Equilibria and an Informationally Efficient and Implementable Mixed-Ownership System, "Journal of Economic Behavior and Organization, 1995, forthcoming.

H. R. Varian, Microeconomic Analysis, W. W. Norton and Company, third edition, 1992. 